\title{
Dose-Dependent Hemodynamic, Biochemical, and Tissue Oxygen Effects of OC99 following Severe Oxygen Debt Produced by Hemorrhagic Shock in Dogs
}

\author{
William W. Muir, ${ }^{1}$ Carlos L. del Rio, ${ }^{1}$ Yukie Ueyama, ${ }^{1}$ Bradley L. Youngblood, ${ }^{1}$ \\ Robert S. George, ${ }^{1}$ Carl W. Rausch, ${ }^{2}$ Billy S. H. Lau, ${ }^{2}$ and Robert L. Hamlin ${ }^{1}$ \\ ${ }^{1}$ QTest Labs, 6456 Fiesta Drive, Columbus, OH 43235, USA \\ ${ }^{2}$ New A Innovation Ltd. 17/F, Chevalier Commercial Centre, 8 Wang Hoi Road, Kowloon Bay, Kowloon, Hong Kong \\ Correspondence should be addressed to William W. Muir; monos369@gmail.com
}

Received 12 July 2014; Revised 21 September 2014; Accepted 30 September 2014; Published 27 October 2014

Academic Editor: Samuel A. Tisherman

Copyright ( $) 2014$ William W. Muir et al. This is an open access article distributed under the Creative Commons Attribution License, which permits unrestricted use, distribution, and reproduction in any medium, provided the original work is properly cited.

\begin{abstract}
We determined the dose-dependent effects of OC99, a novel, stabilized hemoglobin-based oxygen-carrier, on hemodynamics, systemic and pulmonary artery pressures, surrogates of tissue oxygen debt (arterial lactate $7.2 \pm 0.1 \mathrm{mM} / \mathrm{L}$ and arterial base excess $-17.9 \pm 0.5 \mathrm{mM} / \mathrm{L})$, and tissue oxygen tension $\left(\mathrm{tPO}_{2}\right)$ in a dog model of controlled severe oxygen-debt from hemorrhagic shock. The dose/rate for OC99 was established from a pilot study conducted in six bled dogs. Subsequently twenty-four dogs were randomly assigned to one of four groups ( $n=6$ per group) and administered: $0.0,0.065,0.325$, or $0.65 \mathrm{~g} / \mathrm{kg}$ of OC99 combined with $10 \mathrm{~mL} / \mathrm{kg}$ lactated Ringers solution administered in conjunction with $20 \mathrm{~mL} / \mathrm{kg}$ Hextend IV over 60 minutes. The administration of $0.325 \mathrm{~g} / \mathrm{kg}$ and $0.65 \mathrm{~g} / \mathrm{kg}$ OC99 produced plasma hemoglobin concentrations of $0.63 \pm 0.01$ and $1.11 \pm 0.02 \mathrm{~g} / \mathrm{dL}$, respectively, improved systemic hemodynamics, enhanced $\mathrm{tPO}_{2}$, and restored lactate and base excess values compared to 0.0 and $0.065 \mathrm{~g} / \mathrm{kg} \mathrm{OC} 99$. The administration of $0.65 \mathrm{~g} / \mathrm{kg}$ OC99 significantly elevated pulmonary artery pressure. Plasma hemoglobin concentrations of OC99 ranging from 0.3 to $1.1 \mathrm{~g} / \mathrm{dL}$, in conjunction with colloid based fluid resuscitation, normalized clinical surrogates of tissue oxygen debt, improved $\mathrm{tPO}_{2}$, and avoided clinically relevant increases in pulmonary artery pressure.
\end{abstract}

\section{Introduction}

Hemorrhage is a major cause of morbidity and mortality in human and veterinary medicine $[1,2]$. Multiple animal models have established the pathophysiologic consequences of controlled and uncontrolled hemorrhage, the therapeutic importance of the timely return of normal hemodynamic values, and the restoration of microvascular perfusion $[3,4]$. Evidence generated from studies conducted in large animal species (dog, pig, and humans) has identified oxygen debt and tissue oxygen-tension $\left(\mathrm{tPO}_{2}\right)$ values that are predictive of both a therapeutic time window and the fluid replacement volume required to prevent irreversible shock $[3,5,6]$.

Oxygen $\left(\mathrm{O}_{2}\right)$ carrying blood substitutes $\left(\mathrm{O}_{2}\right.$ therapeutics $)$ were developed to address concerns regarding the availability, storage, transport, and safety of the human blood supply $[7,8]$. Multiple cell-free hemoglobin based $\mathrm{O}_{2}$ carriers (HBOCs) and gas-carrying fluids have evolved with most demonstrating the ability to improve hemodynamics, restore tissue oxygen tension, reduce transfusion requirements, and delay definitive care compared to the administration of non-oxygen carrying crystalloids or colloids [9]. Unfortunately, although thoughtfully designed, HBOCs have been fraught with unforeseen dose related adverse effects including vasoconstriction, systemic and pulmonary hypertension, oxidation to methemoglobin, and the possibility of tissue toxicity due to the generation of reactive $\mathrm{O}_{2}$ species, effects that have been primarily attributed to nitric oxide scavenging and extravasation, high P50, and hyperoxygenation [10, 11]. Systemic and pulmonary vasoconstriction are considered a major 
concern following the administration of polymerized bovine $\mathrm{Hb}(\mathrm{PBH})$ to hypovolemic pigs, sheep, and humans [12]. Purity aside, multiple studies have demonstrated that the administration of large doses of concentrated $(13 \mathrm{~g} / \mathrm{dL})$, low affinity (high P50) HBOCs results in systemic and pulmonary vasoconstriction (increased systemic and pulmonary pressures) and a reduction in functional capillary density (FCD; 13). Alternatively, exchange transfusion and hemorrhagic shock experiments examining the effects of lower concentrations $(\leq 8 \mathrm{~g} / \mathrm{dL})$ of a low affinity $(\mathrm{P} 50 \geq 34 \mathrm{~mm} \mathrm{Hg})$ polymerized bovine $\mathrm{Hb}$ suggest that beneficial tissue perfusion pressure, $\mathrm{FCD}$, and $\mathrm{tPO}_{2}$ can be maintained providing plasma $\mathrm{Hb}$ concentrations $\left(\mathrm{Hb}_{\mathrm{p}}\right)$ do not exceed $1.4 \mathrm{~g} / \mathrm{dL}[13,14]$.

We investigated the acute dose response characteristics of a low concentration $(6.5 \mathrm{~g} / \mathrm{dL})$ of highly purified $\mathrm{PBH}$ solution (OC99; New A Innovation Ltd., Kowloon, Hong Kong) on systemic and pulmonary arterial blood pressures, tissue oxygenation, and the metabolic correlates of oxygen debt in an experimental model of controlled hemorrhagic shock in dogs. OC99 dose selection was based upon pilot experiments wherein the $\mathrm{Hb}_{\mathrm{p}}$ concentration that prevented pulmonary hypertension (mean pressure $>25 \mathrm{~mm} \mathrm{Hg}$ ) in hemorrhaged dogs was identified [15]. We hypothesized that OC99 could be administered at doses that would improve $\mathrm{tPO}_{2}$ without producing pulmonary hypertension.

\section{Materials and Methods}

All procedures were reviewed and approved by the Institutional Animal Care and Use Committee at QTest Labs and complied with federal guidelines for the care and use of laboratory animals and were conducted according to the principles in the "Guide for the Care and Use of Laboratory Animals," Institute of Laboratory Animals Resources, Eighth Edition (Washington, D.C.: The National Academies Press, 2011) and the Animal Welfare Act as amended.

Thirty-three young mature male Beagle dogs were acclimated to the animal facility during a seven-day quarantine period. All dogs were determined to be in good health based upon a physical examination, body temperature, heart and respiratory rate, general appearance, auscultation of the thoracic cavity, and palpation of the abdominal cavity. Dogs were individually housed in cages and exercised daily during the in-life phase of the study. The environmental conditions of the animal room were a light/dark cycle set to maintain approximately 12 hours of light and 12 hours of dark each day and a room temperature and relative humidity of 64 to $74^{\circ} \mathrm{F}$ and 30 to $60 \%$, respectively. The room temperature and humidity were recorded hourly and monitored daily. The dogs were provided commercial dry dog food and water ad libitum.

2.1. Animal Preparation. Vascular catheters were placed in the cephalic and saphenous veins for administration of anesthetic drugs (cephalic vein) and treatments (saphenous vein), respectively. Dogs were administered butorphanol, $0.25 \mathrm{mg} / \mathrm{kg} \mathrm{IV}$, and anesthetized with propofol, 3.5 to $6 \mathrm{mg} / \mathrm{kg} \mathrm{IV}$, to facilitate orotracheal intubation. All dogs were mechanically ventilated with a volume-cycled ventilator ( $\sim 12$ breaths $/ \mathrm{min}$, tidal volume: 10 to $15 \mathrm{~mL} / \mathrm{kg}$ ) in order to maintain the arterial blood carbon dioxide $\left(\mathrm{CO}_{2}\right)$ partial pressure $\left(\mathrm{PaCO}_{2}\right)$ between 38 and $48 \mathrm{~mm} \mathrm{Hg}$. Anesthesia was initially maintained with $1.5 \%$ isoflurane in room air. Core body temperature ranged from 37 to $39^{\circ} \mathrm{C}$ and was maintained with temperature-controlled warm air blankets. The dogs were initially placed in right lateral recumbency, skin electrodes were attached, and a catheter introducer was placed in the left jugular vein through which a thermodilution catheter was introduced and positioned with the thermistor in the main pulmonary artery. The left carotid artery was isolated and a dual tipped pressure sensing catheter (Milar, Inc. Houston, TX) was positioned in the ascending aorta and left ventricle, respectively. These catheters permitted the determination of core body temperature $\left({ }^{\circ} \mathrm{C}\right)$, pulmonary artery pressure $(\mathrm{mm} \mathrm{Hg})$, cardiac output $(\mathrm{L} / \mathrm{min})$ via thermodilution (Baxter, Deerfield, IL), and aortic pressure (mm Hg; EMKA Technologies, Falls Church, VA). The left or right femoral artery and vein were isolated and catheterized in order to permit hemorrhage and blood sampling, respectively. Once instrumented the dog was repositioned in dorsal recumbency for the remainder of the experiment. A 5 to $6 \mathrm{~cm}$ midline incision was made through the skin and linea alba and an intestinal loop of gut (jejunum) was exposed. A 20gauge needle was used to establish a tract between the serosa and muscular layers of the intestine for probe placement and determination of intestinal mucosa tissue-oxygen tension ( $\mathrm{mm} \mathrm{Hg}$ ) via optical fluorescence (OxyLite; Oxford Optronix, Abingdon, United Kingdom). The dogs were stabilized for approximately 30-45 minutes following instrumentation and administered 100 units $/ \mathrm{kg} / \mathrm{h}$ IV heparin in order to facilitate hemorrhage and blood sampling. Baseline data were recorded and blood samples obtained for determination of blood $\mathrm{pH}$, gases $\left(\mathrm{PaO}_{2} ; \mathrm{PaCO}_{2}\right)$ and biochemical data (lactate; base excess). Each dog was then hemorrhaged to a mean arterial pressure ranging from 30 to $40 \mathrm{~mm} \mathrm{Hg}$ by controlled bleeding (blood withdrawal or infusion). Hemorrhaged blood was collected into a heparinized collection bag and weighed. Arterial lactate and base excess and their ratio were monitored every 15 minutes during bleeding.

\subsection{Study Design and Treatment Protocols}

2.2.1. Pilot Study. A pilot potency assay was performed in six anesthetized and hemorrhaged dogs weighing $10 \pm 0.3 \mathrm{~kg}$ to determine the plasma hemoglobin concentration $(\mathrm{g} / \mathrm{dL})$ that produced a pulmonary artery pressure $>25 \mathrm{~mm} \mathrm{Hg}$. We considered, a priori, a mean pulmonary artery pressure $>25 \mathrm{~mm} \mathrm{Hg}$ to be hypertensive [15]. Six dogs were prepared as described and administered placebo (2 dogs; Hextend [HEX], Hospira, Inc., Lake Forest, IL) or an intravenous infusion $(10 \mathrm{~mL} / \mathrm{kg})$ of different doses of OC99 every 30 minutes for a total of 4 treatments (i.e., $40 \mathrm{~mL} / \mathrm{kg}$ total). The concentration and rate of OC99 administration varied for each infusion: $0.325 \mathrm{~g} / \mathrm{kg} / 10 \mathrm{~min}$. (1 dog); $0.1 \mathrm{~g} / \mathrm{kg} / 10 \mathrm{~min}$. (1 dog); $0.05 \mathrm{~g} / \mathrm{kg} / 10 \mathrm{~min}$. (1 dog); and $0.325 \mathrm{~g} / \mathrm{kg} / 30 \mathrm{~min}$. (1 dog). All treatments were delivered as volume-matched $(10 \mathrm{~mL} / \mathrm{kg})$ intravenous infusions (OC99 in HEX) to a total volume of 
TABLE 1: Comparison of composition of OC99 (Oxapex), HBOC-301 (Oxyglobin), and HBOC-201 (Hemopure).

\begin{tabular}{|c|c|c|c|}
\hline & OC99 (Oxapex) & HBOC-301 (Oxyglobin) & HBOC-201 (Hemopure) \\
\hline Hemoglobin concentration $(\mathrm{g} / \mathrm{dL})$ & $6-7$ & $12-14$ & $12-14$ \\
\hline Met-hemoglobin (\%) & $\leq 5 \%$ & $<10$ & $<10$ \\
\hline P50 (mmHg) & 39 & 40 & 40 \\
\hline $\mathrm{pH}$ & $7.2-7.6$ & $7.6-7.9$ & $7.6-7.9$ \\
\hline Endotoxin $(\mathrm{EU} / \mathrm{mL})$ & $<0.05$ & $<0.5$ & $<0.5$ \\
\hline Phospholipid (nmol/mL) & nd & $<3$ & $<3$ \\
\hline Colloid osmotic pressure (mmHg) & 19 & 42 & 25 \\
\hline Osmolarity (mOsm/kg) & $250-350$ & 300 & 300 \\
\hline Tetrameric hemoglobin (\%) & $>85$ & $\leq 35$ & $\leq 2$ \\
\hline Average molecular weight $(\mathrm{kDa})$ & 65 & 200 & 250 \\
\hline Viscosity (centripoise at $37^{\circ} \mathrm{C}$ ) & 1.1 & 1.3 & 1.3 \\
\hline Half-life in humans/animals (hours) & $16-55^{*}$ & $18-43$ & 19 \\
\hline Cross-linking agent & bis (3,5-dibromosalicyl) fumarate. & gluteraldehyde & gluteraldehyde \\
\hline Storage conditions $\left({ }^{\circ} \mathrm{C}\right)$ & $<25$ (without freezing) & $2-30$ & $2-30$ \\
\hline
\end{tabular}

${ }^{*}$ Dose dependent; nd: nondetectable.

$10 \mathrm{~mL}$. Hemodynamic data, Hct (\%) total hemoglobin $(\mathrm{Hb}$, $\mathrm{g} / \mathrm{dL}), \mathrm{Hb}_{\mathrm{p}}(\mathrm{g} / \mathrm{dL}), \mathrm{pH}, \mathrm{PO}_{2}(\mathrm{~mm} \mathrm{Hg}), \mathrm{PCO}_{2}$ ( $\mathrm{mm} \mathrm{Hg}$ ), lactate $(\mathrm{mmol} / \mathrm{L}), \mathrm{BE}(\mathrm{mEq} / \mathrm{L})$, venous blood oxygen saturation $\left(\mathrm{SvO}_{2}: \%\right)$, and intestinal mucosa $\mathrm{tPO}_{2}(\mathrm{~mm} \mathrm{Hg})$ were determined immediately before (baseline) and at 5 (except CO), 10, 20 , and 30 minutes after each infusion. Additional data were obtained at 60 and 90 minutes after the last infusion.

2.2.2. Dose-Response Study. A controlled, dose response study was performed in 24 dogs weighing $10.7 \pm 0.2 \mathrm{~kg}$. Six dogs were assigned to one of four treatment groups (6 dogs per group) using a twofold randomization process. Dogs were randomly selected from the colony of enrolled animals. The dogs were bled to a predetermined degree of oxygen debt (oxygen debt $\approx 110 \mathrm{~mL} / \mathrm{kg}$ ) that predicated a $50 \%$ mortality based upon metabolic surrogates (arterial lactate of 6 to $9 \mathrm{mM} / \mathrm{L}$; base excess $>-12 \mathrm{mM} / \mathrm{L} ; 3,5)$. Subsequently, each dog was randomly assigned to receive one of the four treatments. Randomization lists (dog and group) were generated using statistical software (SAS System for Windows, Version 9.1 or higher; SAS Institute Inc., 2004). All test treatments were administered (KD Scientific, Inc.; Holliston, MA) for 60 minutes through the catheter placed in the saphenous vein.

The test articles included OC99 and two non-oxygen carrying control solutions: Lactated Ringer's Solution (LRS; Abbott Laboratories, North Chicago, IL) and 6\% HEX. OC99 is a highly purified and polymerized (bis[3,5-dibromosalicyl] fumurate) bovine $\mathrm{Hb}$ dissolved in Ringer's Acetate solution to a concentration of $6.5 \pm 0.5 \mathrm{~g} / \mathrm{dL}$. OC99 contains greater than $85 \%$ tetramers and has a shelf life of 12 months at $25^{\circ} \mathrm{C}$ (Table 1). Six dogs each were administered (1) $20 \mathrm{~mL} / \mathrm{kg} / \mathrm{h}$ of HEX and $10 \mathrm{~mL} / \mathrm{kg} / \mathrm{hr}$ of LRS (HEX + CTRL/LRS), (2) $20 \mathrm{~mL} / \mathrm{kg} / \mathrm{hr}$ of HEX and $0.065 \mathrm{~g} / \mathrm{kg}$ OC99 (HEX + LOW), (3) $20 \mathrm{~mL} / \mathrm{kg} / \mathrm{h}$ of HEX and $0.325 \mathrm{~g} / \mathrm{kg}$ OC99 (HEX + MID), or (4) $20 \mathrm{~mL} / \mathrm{kg} / \mathrm{h}$ of HEX and $0.65 \mathrm{~g} / \mathrm{kg} \mathrm{OC99}$ (HEX + HIGH). OC99 dosing was completed with a subsequent LRS infusion to a volume of $10 \mathrm{~mL}$ in HEX + LOW and HEX + MID. A total of $30 \mathrm{~mL} / \mathrm{kg}$ fluid was administered over 60 minutes.

Hematological and biochemical data were determined from arterial and venous whole blood samples collected before hemorrhage, every $15 \mathrm{~min}$ during bleeding and at predetermined times for the duration of the 3-hour experiment. The blood samples were analyzed for HCT and $\mathrm{Hb}_{\mathrm{p}}, \mathrm{pH}$, $\mathrm{PO}_{2}, \mathrm{PCO}_{2}$, arterial lactate (La), base excess $(\mathrm{BE})$, and $\mathrm{SvO}_{2}$. The COP was determined at 3 time points: baseline (before hemorrhage), the end of hemorrhage immediately before fluid resuscitation, and at the end of treatment. Hemodynamic parameters were recorded at baseline, immediately before fluid resuscitation, and every 20 minutes after the start of treatment. Data included an electrocardiogram (ECG), heart rate ( $\mathrm{HR}$, beats/min.), mean right-atrial ( $\mathrm{RAP}, \mathrm{mm} \mathrm{Hg}$ ) and pulmonary-artery (PAP, $\mathrm{mm} \mathrm{Hg}$ ) systolic (SAP), diastolic (DAP), and mean (MAP) arterial pressures ( $\mathrm{mm} \mathrm{Hg}$ ), and left ventricular end systolic (LVESP, $\mathrm{mm} \mathrm{Hg}$ ) and end diastolic pressures (LVEDP, mm Hg).

2.3. Statistical Methods. The primary end-points of this study were changes in $\mathrm{Hb}_{\mathrm{p}}$ concentration, tissue oxygenation $\mathrm{tPO}_{2}$ arterial lactate, base deficit, and $\mathrm{SvO}_{2}$. All statistical tests were performed using computer software (SAS System for Windows, Version 9 of the programs; SAS Institute Inc., 2004). Statistical analyses were performed separately for each parameter. All data are reported as the mean \pm the standard error of the mean (SEM). The analysis of variance for repeated measures (ANOVA) included dose, time, and the interaction of dose and time as fixed effects, and the animal as a random effect. The model took into account the correlations in the postdosing averages that were present due to monitoring the same animals over multiple time points following a given dosing through the use of a covariance structure. If the $F$-value exceeded the critical value, post hoc (Holm-Sidak) tests were conducted within the ANOVA 
to test for significant differences among dose groups/time intervals. A Benjamini and Hochberg method was utilized to control for the false discovery rate for these tests across all time intervals. Bonferroni corrections were applied, when applicable, to the significance levels of multiple comparisons in order to control the overall error rate associated with each dose group comparisons at a given time interval to no more than 5\%. The significant level was $P<0.05$ and values below $P<0.1$ level were considered as indication of a notable trend.

\section{Results}

3.1. Pilot Dose Determination Experiments. Controlled hemorrhage $(51 \pm 3 \mathrm{~mL} / \mathrm{kg})$ produced anticipated hemodynamic and blood chemical changes consistent with the development of hypovolemic shock and oxygen imbalance. Mean systemic and pulmonary arterial blood pressure significantly decreased (MAP: $110 \pm 6$ to $43 \pm 2 \mathrm{~mm} \mathrm{Hg}$; PAP: $18 \pm 1$ to $9 \pm$ $1 \mathrm{~mm} \mathrm{Hg})$. Cardiac output (CO: $1.4 \pm 0.1$ to $0.4 \pm 0.0 \mathrm{~L} / \mathrm{min}$ ) and left ventricular end diastolic pressure (LVEDP: $10 \pm$ 1 to $1 \pm 1 \mathrm{~mm} \mathrm{Hg}$ ) significantly decreased associated with significant $(P<0.05)$ increases in heart rate (HR: $123 \pm 5$ to $195 \pm 16 \mathrm{bpm})$. The $\mathrm{tPO}_{2}$ was significantly decreased $(31 \pm 8$ to $2 \pm 3 \mathrm{~mm} \mathrm{Hg}$ ) after hemorrhage. Systemic and pulmonary vascular resistance values significantly increased after hemorrhage (dyn·sec/cm ${ }^{5}$ : SVR: $6042 \pm 387$ to $9056 \pm 308$; PVR: $491 \pm 94$ to $2180 \pm 359)$. Blood arterial lactate significantly increased (La: $1.4 \pm 0.1$ to $4.5 \pm 0.5 \mathrm{mM} / \mathrm{L}$ ) while arterial base excess (BE: $-7 \pm 1$ to $-13 \pm 1 \mathrm{mM} / \mathrm{L}$ ) and venous oxygen saturation $\left(\mathrm{SvO}_{2}: 80 \pm 3\right.$ to $24 \pm 4 \%$, ) decreased significantly.

Infusion of OC99 produced dose and rate of administration dependent increases in $\mathrm{Hb}_{\mathrm{p}}$. The $\mathrm{Hb}_{\mathrm{p}}$ concentrations after the first and second infusions for the three doses of OC99 $(0.325,0.1$, and $0.05 \mathrm{~g} / \mathrm{kg})$ administered over 10 minutes were $0.84,0.34$, and $0.20 \mathrm{~g} / \mathrm{dL}$ and $1.26,0.48$, and $0.27 \mathrm{~g} / \mathrm{dL}$, respectively. The infusion of OC99 produced $\mathrm{Hb}_{\mathrm{p}}$ concentration dependent increases in $\mathrm{tPO}_{2}$ in the intestinal mucosa. The greatest increases in $\mathrm{tPO}_{2}$ occurred at a $\mathrm{Hb}_{\mathrm{p}}$ concentration averaging $0.84 \pm 0.13 \mathrm{~g} / \mathrm{dL}$. The administration of HEX infusions containing OC99 produced $\mathrm{Hb}_{\mathrm{p}}$ concentrations below $0.3 \mathrm{~g} / \mathrm{dL}$ resulting in little or no change in $\mathrm{PAP}$ or $\mathrm{tPO}_{2}$ $\left(\mathrm{tPO}_{2}<10 \mathrm{~mm} \mathrm{Hg}\right.$; Figure 1). Infusion of HEX $(0.0 \mathrm{~g} / \mathrm{kg})$ and the first dose $(0.05 \mathrm{~g} / \mathrm{kg})$ of OC99 failed to attain this plasma concentration. The administration of repeat doses of OC99 resulting in $\mathrm{Hb}_{\mathrm{p}}$ values greater than $0.3 \mathrm{~g} / \mathrm{dL}$ increased pulmonary artery pressure; $\mathrm{Hb}_{\mathrm{p}}$ concentration was an independent predictor of the mean pulmonary artery pressure (Figure 1). Pulmonary artery pressures exceeded $25 \mathrm{~mm} \mathrm{Hg}$ when repeat dosages of $0.325 \mathrm{~g} / \mathrm{kg}$ OC99 were administered over 10 minutes. We considered, a priori, a mean pulmonary artery pressure $>25 \mathrm{~mm} \mathrm{Hg}$ to be hypertensive [16]. The slower infusion of OC99 $(0.325 \mathrm{~g} / \mathrm{kg}$ over $30 \mathrm{~min})$ prevented the increase in PAP. Based upon these results we hypothesized that the slow administration of OC99 to hemorrhaged dogs would increase $\mathrm{tPO}_{2}$ without producing pulmonary hypertension (i.e., mean PAP $>25 \mathrm{~mm} \mathrm{Hg}$ ) and when $\mathrm{Hb}_{\mathrm{p}}$ concentration was less than $1.1 \mathrm{~g} / \mathrm{dL}$. Subsequent dose response experiments were designed to encompass
TABLE 2: Representative systemic/left-ventricular hemodynamic, mechanical, and metabolic parameters measured before (i.e., at baseline) and after the induction of shock/oxygen imbalance via controlled hemorrhage in the isoflurane anesthetized closed-chest canine preparation.

\begin{tabular}{|c|c|c|}
\hline \multicolumn{3}{|c|}{ Model characteristics $(n=24)$} \\
\hline Parameter (units) & Baseline & Hemorrhagic shock $^{5}$ \\
\hline Hematocrit, PCV $(\%)^{4}$ & $41.9(1.2)$ & $40.5(0.9)$ \\
\hline Total Hb (g/dL) & $14.3(0.4)$ & $13.8(0.3)$ \\
\hline Plasma Hb (g/dL) & $0.06(0.01)$ & $0.07(0.01)$ \\
\hline MAP (mmHg) & $105(3)$ & $40(1)^{*}$ \\
\hline SVR (dyne $/ \mathrm{cm} / \mathrm{s}^{-5}$ ) & $4,192(121)$ & $7,053(305)^{*}$ \\
\hline PAP $(\mathrm{mmHg})$ & $20.4(0.6)$ & $14.6(0.5)^{*}$ \\
\hline PVR (dyne $/ \mathrm{cm} / \mathrm{s}^{-5}$ ) & $471(18)$ & $2,584(199)^{*}$ \\
\hline $\mathrm{HR}(\mathrm{bpm})$ & $131(4)$ & $212(5)^{*}$ \\
\hline $\mathrm{LV}-\mathrm{dP} / \mathrm{dt}_{\max }(\mathrm{mmHg} / \mathrm{s})^{1}$ & $+2,249(85)$ & $+1,214(52)^{*}$ \\
\hline $\mathrm{LV}-\mathrm{dP} / \mathrm{dt}_{\min }(\mathrm{mmHg} / \mathrm{s})^{1}$ & $-2,152(82)$ & $-822(42)^{*}$ \\
\hline Cardiac output $(\mathrm{L} / \mathrm{min})^{2}$ & $1.9(0.1)$ & $0.4(0.0)^{*}$ \\
\hline Oxygen extraction ratio (\%) & $12.8(0.9)$ & $67.6(1.2)^{*}$ \\
\hline $\mathrm{PaO}_{2}(\mathrm{mmHg})$ & $82.5(1.5)$ & $86.4(1.4)^{*}$ \\
\hline $\mathrm{PaCO}_{2}(\mathrm{mmHg})$ & $38.9(0.6)$ & $27.9(0.9)^{*}$ \\
\hline $\mathrm{tPO}_{2}(\mathrm{mmHg})^{3}$ & $32.2(1.6)$ & $2.7(0.6)^{*}$ \\
\hline $\mathrm{pHa}$ & $7.30(0.01)$ & $7.19(0.01)^{*}$ \\
\hline $\mathrm{BE}(\mathrm{mM} / \mathrm{L})^{4}$ & $-7.2(0.4)$ & $-17.5(0.6)^{*}$ \\
\hline $\mathrm{LA}(\mathrm{mM} / \mathrm{L})^{4}$ & $2.2(0.1)$ & $7.2(0.2)^{*}$ \\
\hline $\mathrm{SvO}_{2}(\%)$ & $82.6(0.9)$ & $30.4(1.1)^{*}$ \\
\hline
\end{tabular}

Data are mean values (standard error of the mean).

${ }^{1}$ Derived from left-ventricular pressure (LVP) signals.

${ }^{2}$ Measured/derived via thermodilution.

${ }^{3}$ Measured directly via optical fluorescence in the intestine.

${ }^{4}$ Measured/derived from arterial blood samples.

${ }^{5}$ The average volume of blood shed during the hemorrhagic shock period was $644 \pm 18 \mathrm{~mL}$.

${ }^{*} P<0.05$ (statistically significant) versus baseline.

OC99 $\mathrm{Hb}_{\mathrm{p}}$ concentrations $(0.3-1.1 \mathrm{gm} / \mathrm{dL})$ that improved $\mathrm{tPO}_{2}$ without producing pulmonary hypertension.

\section{Dose Response Experiments}

Twenty-seven dogs were subjected to controlled hemorrhage. Two animals died during or immediately after hemorrhage and were not considered for analysis, while one dog did not meet entry criteria for lactate and base-deficit.

Data were collected and analyzed from twenty-four dogs. Baseline hemodynamic, blood chemistry, and tissue oxygenation values were considered to be within the normal range for dogs (Table 2). Controlled hemorrhage (644 \pm $18 \mathrm{~mL} ; 60 \pm 2 \mathrm{~mL} / \mathrm{kg}$ ) produced the targeted metabolic end points (i.e., entry criteria LA 6 to $9 \mathrm{mM} / \mathrm{L} ; \mathrm{BE}>-12 \mathrm{mM} / \mathrm{L}$ ) in $69 \pm 4$ min. Significant hemodynamic and metabolic changes consistent with the development of hypovolemic shock and oxygen imbalance were produced in all dogs (Table 2). 

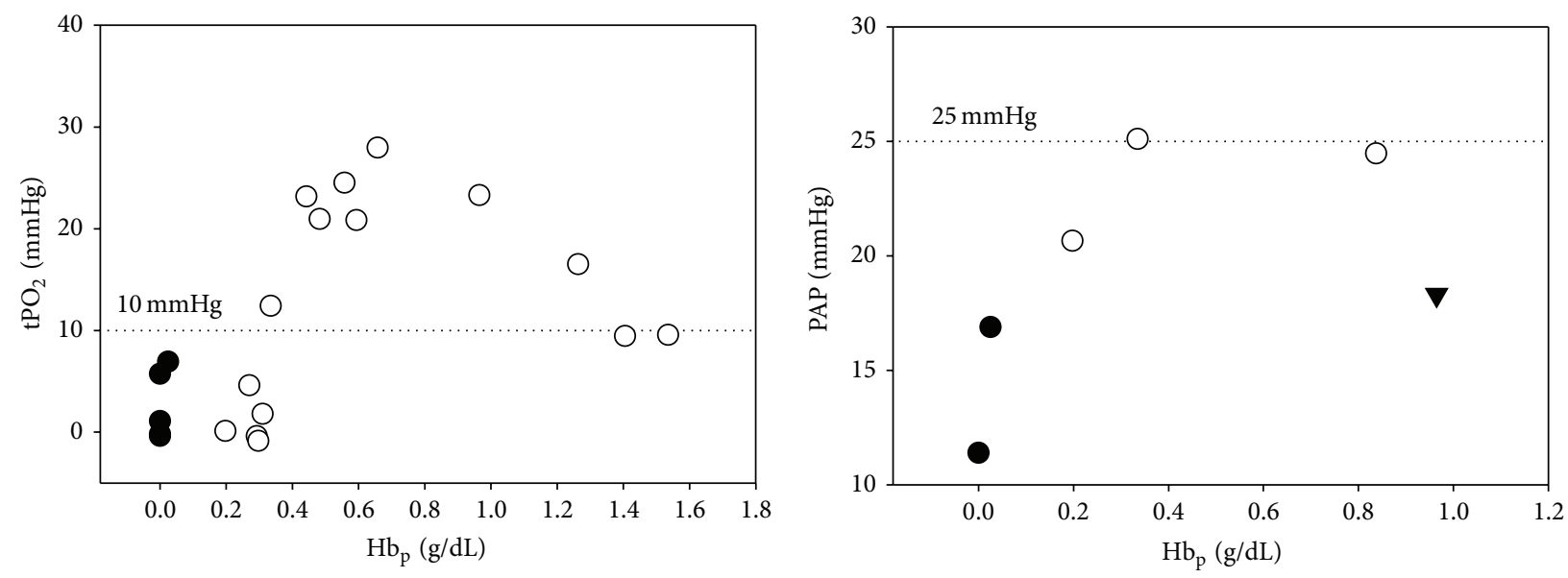

- Control

○ OC99

(a)

(b)

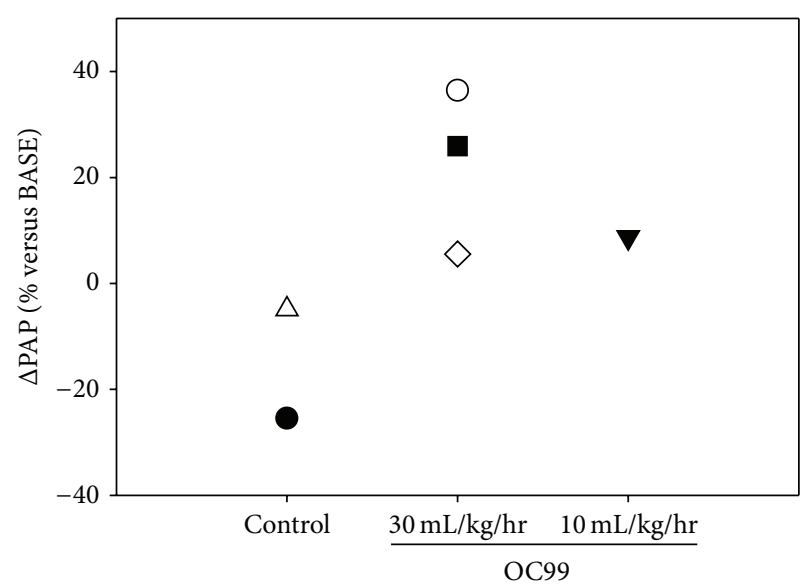

(c)

FIGURE 1: (a) OC99 plasma hemoglobin $\left(\mathrm{Hb}_{\mathrm{p}}\right)$ concentration versus tissue oxygen tension $\left(\mathrm{tPO}_{2}\right)$. (b) $\mathrm{OC}_{9} \mathrm{Hb}_{\mathrm{p}}$ concentration versus mean pulmonary artery (PAP) pressure. (c) Change in PAP when $0.65 \mathrm{~g} / \mathrm{kg}$ OC99 is administered at $30 \mathrm{ml} / \mathrm{kg} / \mathrm{hr}$ or $10 \mathrm{ml} / \mathrm{kg} / \mathrm{hr}$; each symbol represents a different dog. Solid circles: Hextend without OC99; open circles: repeat doses of Hextend with increasing concentrations of OC99 administered over 10 minutes. Solid triangle: Hextend with OC99 administered over 30 minutes.

Systemic and pulmonary arterial blood pressures (MAP: $40 \pm$ $1 \mathrm{~mm} \mathrm{Hg}$; PAP: $20 \pm 0.5$ to $14 \pm 0.4 \mathrm{~mm} \mathrm{Hg}$ ), cardiac output (CO: $0.4 \pm 0.0 \mathrm{~L} / \mathrm{min})$, and left ventricular filling pressures (LVEDP: $2 \pm 0.3 \mathrm{~mm} \mathrm{Hg})$ were significantly $(P<0.05)$ decreased and heart rate $(210 \pm 5 \mathrm{bpm})$ was significantly increased in all dogs. Systemic and pulmonary vascular resistance significantly increased after hemorrhage (Table 2). Oxygen extraction $\left(\mathrm{ERO}_{2}\right)$ significantly increased. Intestinal $\mathrm{tPO}_{2}$ significantly decreased and arterial LA and BE were significantly increased (Table 2 ).

Fluid resuscitation $(30 \mathrm{~mL} / \mathrm{kg}$ over $60 \mathrm{~min})$ produced acute significant changes in the magnitude and sustainability of hemodynamic and blood chemical values in all fluid treatment groups. Larger doses of OC99 $(0.325 \mathrm{~g} / \mathrm{kg}$; $0.65 \mathrm{~g} / \mathrm{kg}$ ) normalized or improved systemic pressures, CO and biochemical markers of anaerobic metabolism (LA, BE), and $\mathrm{tPO}_{2}$ (Table 3). Increasing $\mathrm{Hb}_{\mathrm{p}}$ concentrations of OC99 increased PAP (Figure 2). The administration of $0.650 \mathrm{~g} / \mathrm{kg}$ OC99 produced a significant increase in both SVR and PVR, and mean PAP at the end of dosing (Tables 3 and 4).

There were no significant differences in posttreatment hematocrit concentration(s) among groups (Table 3). Increases in $\mathrm{tPO}_{2}$ were independent of $\mathrm{Hct}$ and $\mathrm{COP}$ and dependent upon OC99 $\mathrm{Hb}_{\mathrm{p}}$ concentration (Table 3; Figure 3). Posttreatment $\mathrm{tPO}_{2}$ values $>10 \mathrm{~mm} \mathrm{Hg}$ were maintained for a longer duration in dogs administered 0.325 and $0.65 \mathrm{~g} / \mathrm{kg}$ OC 99 (Table 5). Dogs administered 0.325 and $0.65 \mathrm{~g} / \mathrm{kg}$ OC $99 \mathrm{had}$ significantly improved LA and BE values at the end of the study (i.e., at END) when compared to values after hemorrhage (Table 3). 


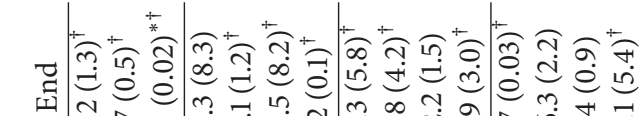

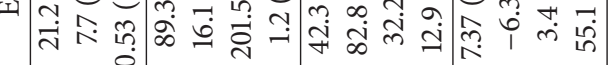

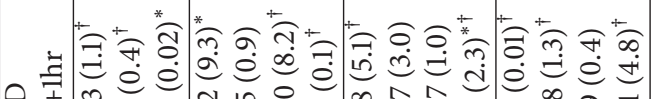

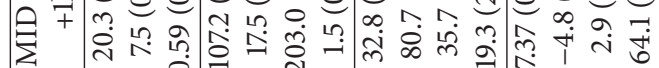
$\sum$

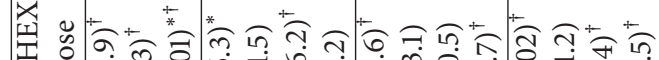

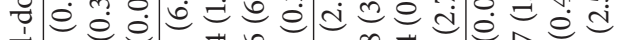
島忽零

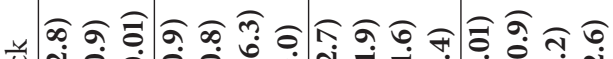
प

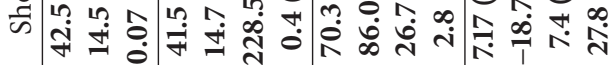

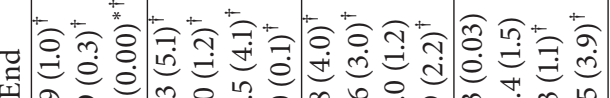
ఏे bे

온

年

空

苛

要

을

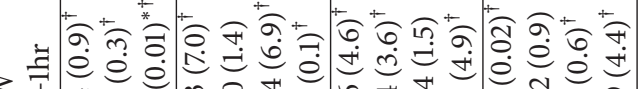

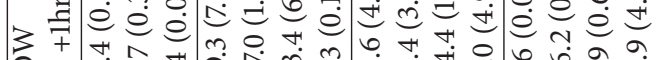
苜

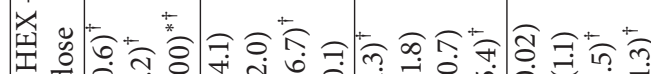

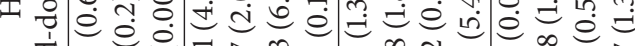

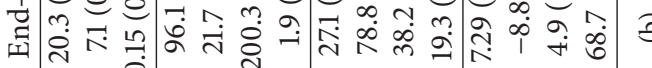
늘 ऊ

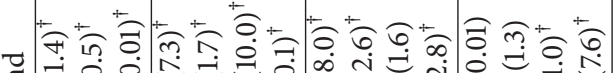

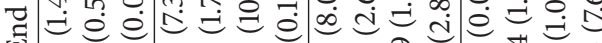

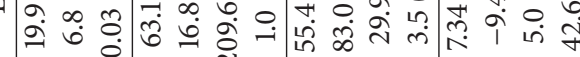

离

살

U

齐

\&

蛋

ङ

突完

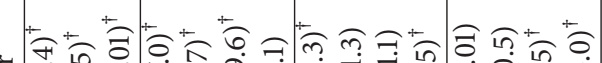

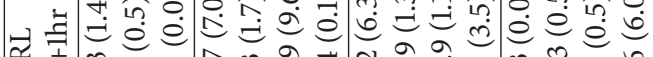

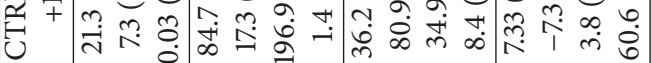

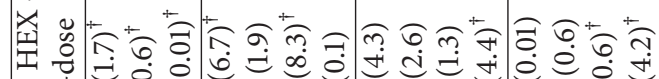

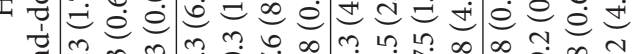

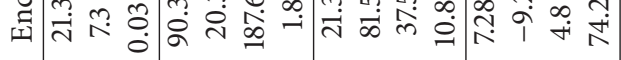

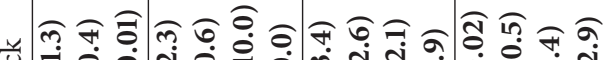
प

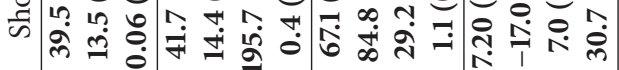

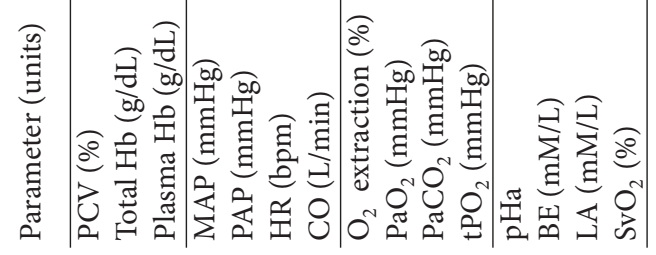

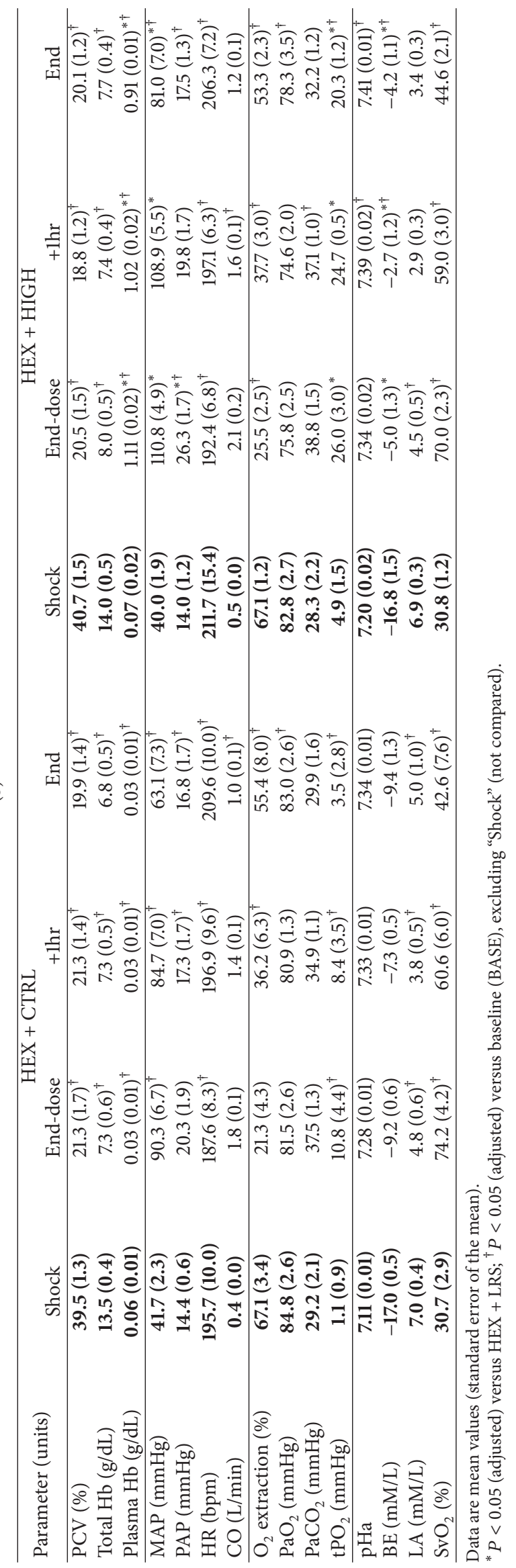




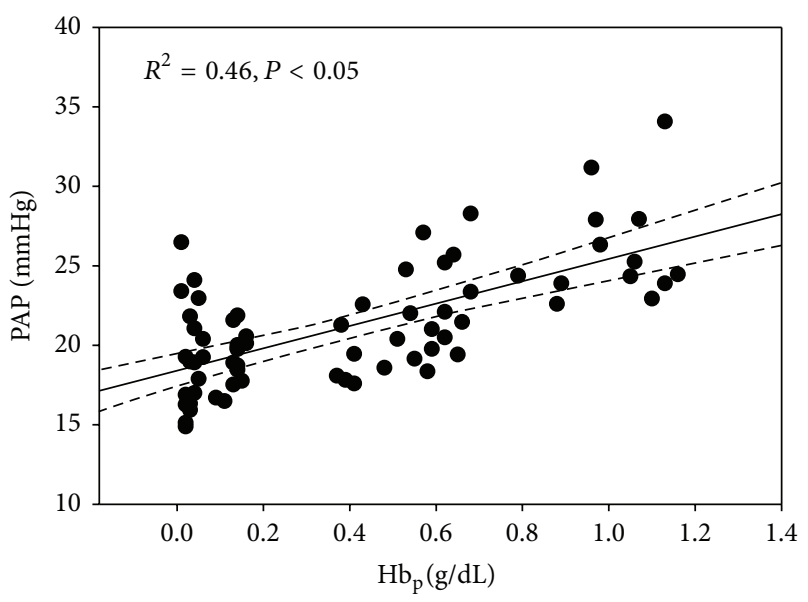

FIGURE 2: Effect of increasing plasma hemoglobin $\left(\mathrm{Hb}_{\mathrm{p}}\right)$ concentrations on mean pulmonary artery pressure (PAP) in hemorrhaged dogs.

TABLE 4: Means (with standard errors) for the plasma colloidosmotic-pressure (COP) as well as the systemic (SVR) and pulmonary (PVR) vascular resistances as measured/estimated at baseline (Base) and at the end of treatment (End-dose).

\begin{tabular}{lccc}
\hline Parameter (units)/group & Baseline & End-dose & \%Change \\
\hline COP (mmHg) & & & \\
HEX + CTRL & $16.5(0.5)$ & $14.6(0.4)$ & $-11.1(2.2)$ \\
HEX + LOW & $16.3(0.9)$ & $14.6(0.6)$ & $-9.6(4.5)$ \\
HEX + MID & $16.4(1.1)$ & $16.6(1.1)$ & $1.7(5.4)$ \\
HEX + HIGH & $15.7(0.9)$ & $17.4(0.7)$ & $11.2(3.3)$ \\
SVR (dyne/cm/s $\left.{ }^{-5}\right)$ & & & \\
HEX + CTRL & $4,560(171)$ & $3,743(236)$ & $-17.9(4.6)$ \\
HEX + LOW & $4,201(378)$ & $3,975(417)$ & $-3.3(8.9)$ \\
HEX + MID & $4,160(110)$ & $4,415(270)$ & $6.3(6.6)$ \\
HEX + HIGH & $3,845(187)$ & $4,293(205)$ & $13.4(8.8)^{*}$ \\
PVR (dyne/cm/s $\left.{ }^{-5}\right)$ & & & \\
HEX + CTRL & $485(51)$ & $647(75)$ & $35.0(9.5)$ \\
HEX + LOW & $507(47)$ & $734(83)$ & $45.3(12.6)$ \\
HEX + MID & $440(9)$ & $676(62)$ & $53.4(13.5)$ \\
HEX + HIGH & $452(17)$ & $881(70)^{*}$ & $96.2(16.2)^{*}$ \\
\hline
\end{tabular}

Data are mean values (standard error of the mean).

${ }^{*} P<0.05$ (adjusted) versus HEX + LRS.

\section{Discussion}

We determined the effects of increasing circulating concentrations of a highly purified PBH (OC99) on hemodynamics, metabolic correlates of oxygen debt (lactate, base deficit), and tissue oxygenation in a large animal model of controlled hemorrhagic shock. The administration of $0.325 \mathrm{~g} / \mathrm{kg}$ of OC99 (plasma $\mathrm{Hb} \sim 0.6 \mathrm{~g} / \mathrm{dL}$ ) in conjunction with a colloid (Hextend) improved hemodynamics and $\mathrm{tPO}_{2}$ without producing significant increases in pulmonary artery blood pressure. The administration of $0.650 \mathrm{~g} / \mathrm{kg}$ OC99 (plasma $\mathrm{Hb} \sim 1.0$ $\mathrm{g} / \mathrm{dL}$ ) produced further increases in $\mathrm{tPO}_{2}$ and increased mean pulmonary arterial pressure to values greater than $25 \mathrm{~mm} \mathrm{Hg}$.

Multiple studies conducted in various experimental animal shock (anemia, controlled and uncontrolled hemorrhage) models have demonstrated the ability of various HBOC solutions to improve hemodynamics, blood oxygen content, oxygen delivery, $\mathrm{tPO}_{2}$, and survival [13, 16-21]. Whether or not the beneficial effects produced translate to clinical benefit however remains controversial based upon the potential for most HBOCs to produce oxidative stress, vasoconstriction, and methemoglobinemia [11]. Oxidation of cell-free $\mathrm{Hb}$ results in methemoglobin (heme- $\mathrm{Fe}^{+2}$ ) limiting the ability of $\mathrm{Hb}$ to carry oxygen and facilitating the production of tissue injury by free radicals [22]. Vasoconstriction is primarily attributed to the extravasation of cell-free $\mathrm{Hb}$ molecules through the endothelium with subsequent binding to nitric oxide produced by endothelial cells and to hyperoxygenation [22, 23]. Hyperoxygenation interferes with small vessel autoregulatory oxygen sensing mechanisms that normally trigger pulmonary arterial vasoconstriction and systemic arterial vasodilation when $\mathrm{PaO}_{2}$ decreases [11]. Additional factors that may contribute to vasoconstriction include the effects of cell-free $\mathrm{Hb}$ on endothelin release, adrenergic receptor activation, and the metabolism of arachidonic acid [22]. Systemic and pulmonary vasoconstriction may result in systemic or pulmonary hypertension, an increase in afterload leading to a decrease in cardiac output, myocardial energetic imbalance, ventilation-perfusion mismatch, a reduction in tissue perfusion, and heterogeneous changes in regional tissue perfusion. Furthermore, an increase in systemic pressure does not necessarily translate to increased perfusion of the microcirculation if arteriolar vasoconstriction is excessive or heterogeneous among tissue beds $[14,24]$.

Experimental studies in anesthetized dogs and swine that have been bled to a mean systemic arterial pressure of $50 \mathrm{~mm} \mathrm{Hg}$ and conscious hemorrhaged and anemic hamsters implanted with window-chambers in their cheek pouches in order to visualize the microcirculation indicate that the administration of a $12-13 \mathrm{~g} / \mathrm{dL}$ HBOC solution failed to return cardiac output and oxygen delivery to baseline values and reduced functional capillary density (the numbers/length of capillaries per unit area of tissue with visible RBC transit), respectively, despite an increase in blood oxygen content $[13,21,25,26]$. Notably, a decrease in FCD has been directly linked to survival while vasoactive activity has been linked to $\mathrm{NO}$ scavenging, $\mathrm{Hb}_{\mathrm{p}}$, and enhanced tissue oxygen tension [26]. Subsequent experiments, however, in severely hemorrhaged ( $\geq 50 \%$ blood volume) conscious hamsters, have demonstrated that administration of reduced concentrations of 4 to $8 \mathrm{~g} / \mathrm{dL}$ HBOC maintained blood pressure without significant vasoconstriction and increased arteriolar oxygen supply and $\mathrm{tPO}_{2}$ [27]. These studies emphasize that the severity of blood loss is a determinant of the probability of a beneficial response to a HBOC (i.e., > blood loss produced better response) and the importance of the dose $(\mathrm{mL} /$ $\mathrm{kg})$, concentration $(\mathrm{g} / \mathrm{dL})$, and rate of administration of the HBOC in determining $\mathrm{Hb}_{\mathrm{p}}$ concentration and their subsequent efficacy and safety. This information combined 


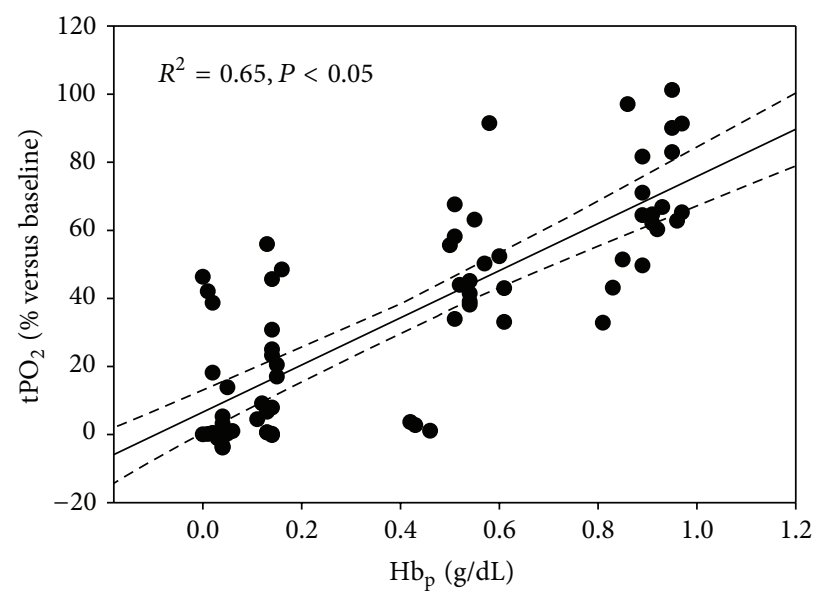

(a)

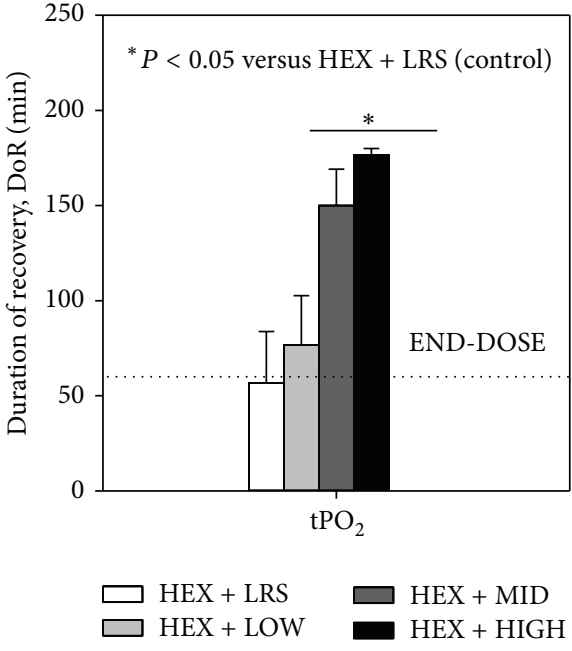

(b)

Figure 3: Effect of increasing plasma hemoglobin $\left(\mathrm{Hb}_{\mathrm{p}}\right)$ concentrations on tissue oxygen tension $\left(\mathrm{tPO}_{2}\right)$ in hemorrhaged dogs. (a) Twodimensional plot of $\mathrm{Hb}_{\mathrm{p}} \mathrm{vs} \mathrm{tPO}_{2}$. (b) Effect of increasing $\mathrm{Hb}_{\mathrm{p}}$ on the duration of $\mathrm{tPO}_{2}$ above $10 \mathrm{~mm} \mathrm{Hg}$.

TABLE 5: Indices indicative of both hemodynamic (systolic blood pressure, SBP) and oxygenation (tissue oxygen tension, $\mathrm{TO}_{2}$ ) recovery ${ }^{1}$ following the administration of either the placebo (LRS) or the test article (OC99): time to recovery (TtR) and duration of recovery (DoR).

\begin{tabular}{|c|c|c|c|c|c|c|}
\hline \multirow{2}{*}{ Group $^{\dagger, \ddagger}$} & \multicolumn{3}{|c|}{$\mathrm{tPO}_{2}(>10 \mathrm{mmHg})$} & \multicolumn{3}{|c|}{$\mathrm{SBP}(>90 \mathrm{mmHg})$} \\
\hline & $\operatorname{TtR}(\min )$ & $\operatorname{DoR}(\min )$ & $\%^{2}$ & $\operatorname{TtR}(\min )$ & $\operatorname{DoR}(\min )$ & $\%^{2}$ \\
\hline HEX + CTRL & $50.0(19.1)$ & $56.7(27.0)$ & $2 / 6$ & $26.7(4.2)$ & $136.7(15.8)$ & $2 / 6$ \\
\hline HEX + LOW & $35.0(9.6)$ & $76.7(26.0)$ & $4 / 6$ & $23.3(3.3)$ & $150.0(13.4)$ & $6 / 6$ \\
\hline HEX + MID & $33.3(6.7)$ & $150.0(19.1)^{*}$ & $6 / 6$ & $20.0(0.0)$ & $170.0(10.0)$ & $6 / 6$ \\
\hline $\mathrm{HEX}+\mathrm{HIGH}$ & $23.3(3.3)$ & $176.7(3.3)^{*}$ & $6 / 6$ & $20.0(0.0)$ & $180.0(0.0)^{*}$ & $6 / 6$ \\
\hline$P$-value & 0.8415 & 0.0005 & & 0.4402 & 0.0178 & \\
\hline
\end{tabular}

Data are mean values (standard error of the mean).

${ }^{1}$ For the purposes of this study, "oxygenation" and "hemodynamic" recovery were defined as the time point(s) when the tissue (intestinal) oxygen tension $\left(\mathrm{TO}_{2}\right)$ and the systemic (systolic) blood pressure (SBP) (resp.) reached values associated with sustainable normal physiological function $\left(\mathrm{TO} \mathrm{O}_{2}>10 \mathrm{mmHg}\right.$, $\mathrm{SBP}>90 \mathrm{mmHg})$.

${ }^{2}$ The ratio of the number of animals that reached the set threshold level. For the $\mathrm{TO}_{2}$ parameter, there were 2 animals from the HEX $+\mathrm{LRS}$ group and 2 animals from the HEX + LOW group that did not reach the set threshold level.

${ }^{\dagger}$ Treatments delivered via continuous IV infusion over $60 \mathrm{~min}$ at $10 \mathrm{~mL} / \mathrm{kg} / \mathrm{hr}$ (combined) in the setting of fluid-resuscitation (20 mL/kg at $\left.20 \mathrm{~mL} / \mathrm{kg} / \mathrm{hr}\right) \mathrm{with}$ either Hextend (HEX+) or LRS (LRS + ); end of dosing (DOSE $\mathrm{END})$ is time zero $(t=0 \mathrm{hr}$ ), while END is the mean value readings taken 2 hours after dosing $(140,160$, and $180 \mathrm{~min})$.

${ }^{\ddagger} \mathrm{LRS}(n=6): 10 \mathrm{~mL} / \mathrm{kg}$ of LRS; LOW $(n=6): 1 \mathrm{~mL} / \mathrm{kg}$ of OC99 $+9 \mathrm{~mL} / \mathrm{kg}$ of LRS; MID $(n=6): 5 \mathrm{~mL} / \mathrm{kg}$ of OC99 + $5 \mathrm{~mL} / \mathrm{kg}$ of LRS; HIGH $(n=6): 10 \mathrm{~mL} / \mathrm{kg}$ of OC99.

${ }^{*} P<0.05$ (adjusted) versus HEX + LRS.

with knowledge of the increased sensitivity of the pulmonary vasculature to the vasoconstrictive effects of $\mathrm{HBOC}$ solutions support the opinion that HBOC solutions should be considered as drugs and that their administration should be guided by the $\mathrm{Hb}_{\mathrm{p}}$ concentration, pharmacokinetics, and the setting (anemia versus hemorrhage) in which they are administered $[12,28]$.

We utilized a validated hypovolemic hemorrhagic acute shock model designed to produce severe oxygen imbalance, resulting in the accumulation of oxygen debt resulting in a mortality $>50 \%$ within 2 to 3 hours [5]. Heparin was administered to facilitate hemorrhage and blood sampling and may have interfered with inflammatory cell adhesion to the vascular endothelium thereby blunting the inflammatory response to hemorrhage $[29,30]$. Our experiments were not designed to assess the effects of OC99 on the inflammatory cascade after shock, but to evaluate the effects of varying degrees of OC99 on hemodynamics and tissue oxygenation, variables that were unlikely to be affected by heparin administration. The administration of OC99 dose dependently normalized surrogates of oxygen debt (lactate and base deficit) and improved gut $\mathrm{tPO}_{2}$. Importantly, dogs administered 0.325 and $0.650 \mathrm{~g} / \mathrm{kg}$ OC99 demonstrated increases in $\mathrm{tPO}_{2}$ to values previously demonstrated, in skeletal muscle and 
gut $[31,32]$, to be physiologically relevant $(>10 \mathrm{~mm} \mathrm{Hg})$ and maintained these values for a significantly longer time than controls $(0.0 \mathrm{~g} / \mathrm{dL})$. These effects became evident by the end of OC99 administration and were independent of both the intrinsic oxygen-carrying capability of the blood (i.e., Hct) and the resuscitation therapy administered (i.e., COP matched). The administration of 0.325 and $0.650 \mathrm{~g} / \mathrm{kg}$ of OC99 exerted salutary effects on all variables associated with oxygen delivery, biochemical markers (LA and $\mathrm{BE}$ ), and $\mathrm{tPO}_{2}$ leading to better recovery after hemorrhage compared to control dogs. Notably, the administration of $0.325 \mathrm{~g} / \mathrm{kg}$ OC99 did not produce clinically relevant increases in PAP (i.e., $>25 \mathrm{~mm} \mathrm{Hg}$ ) while $0.65 \mathrm{~g} / \mathrm{kg}$ OC99 resulted in a pulmonary vasopressor effect by the end of the dosing period $(26 \%$ increase from prehemorrhage values). Experimental studies in hemorrhaged swine and newborn lambs suggest that the pulmonary vasopressor effect is caused by cell free $\mathrm{Hb}_{\mathrm{p}}$ and NO dysregulation and that breathing low levels (30-80 ppm) of NO or administration of various NO donors (nitroglycerin, sodium nitroprusside, and sodium nitrite) is palliative $[33,34]$. Dissimilarities between systemic and pulmonary vasoconstrictive responses to cell-free $\mathrm{Hb}$ are attributed to phenotypic differences and a greater dependency of the muscularized pulmonary circulation to the vasoregulatory effects of NO [35].

Our studies indicate that the administration of 0.325 and $0.650 \mathrm{~g} / \mathrm{kg}$ OC99 produced $\mathrm{Hb}_{\mathrm{p}}$ concentrations ranging from approximately $0.4 \mathrm{~g} / \mathrm{dL}$ and $1.1 \mathrm{~g} / \mathrm{dL}$, respectively, and that $\mathrm{Hb}_{\mathrm{p}}$ values $\leq 0.8 \mathrm{~g} / \mathrm{dL}$ do not produce a significant increase in pulmonary artery pressure. The data support and extend earlier studies investigating the systemic, pulmonary, and microcirculatory effects of $\mathrm{HBOCs}$ by identifying that $\mathrm{Hb}_{\mathrm{p}}$ concentrations greater than $1.1 \mathrm{~g} / \mathrm{dL}$ may cause systemic and pulmonary vasoconstriction limiting increases in tPO2 [14, 36]. Although this study was not designed to demonstrate improved survival two dogs in the low OC99 dose group $(0.065 \mathrm{~g} / \mathrm{kg})$ died before the $180 \mathrm{~min}$ postdosing time point. No other premature deaths were observed and the hemodynamic and biochemical values recorded from these animals were similar to dogs in the control group suggesting that their death was likely attributable to the severity of the experimental procedures.

In conclusion, relatively low OC99 $\mathrm{Hb}_{\mathrm{p}}$ concentrations augment tissue oxygen tension without producing adverse systemic or pulmonary vascular consequences. The administration of OC99 in conjunction with standard colloid-based fluid resuscitation produced dose-dependent increases in $\mathrm{Hb}_{\mathrm{p}}$ concentration, systemic and pulmonary artery pressures, oxygen delivery, $\mathrm{tPO}_{2}$, and normalized clinical surrogates of tissue oxygen debt in a dog model of severe controlled hemorrhagic shock. These effects were independent of Hct and COP and suggest that OC99 can be administered as an adjunct to standard replacement fluid therapy to improve tissue oxygenation following hemorrhage. The data also suggest that pulmonary artery pressure is a more sensitive indicator of the response to cell-free $\mathrm{Hb}_{\mathrm{p}}$ concentration than systemic pressure and should be monitored in order to avoid the potentially detrimental effects of vasoconstriction.

\section{Conflict of Interests}

William W. Muir, Carlos L. del Rio, and Robert L. Hamlin are consultants for New A Innovation Ltd. Carl W. Rausch is a Scientific Advisor to New A Innovation Ltd. Billy S-H Lau is a Manager in the Research and Development group of New A Innovation. For the remaining authors none were declared. This work was supported by New A Innovation Ltd. 17/F, Chevalier Commercial Centre, 8 Wang Hoi Road, Kowloon Bay, Kowloon, Hong Kong.

\section{References}

[1] R. A. Pedowitz and S. R. Shackford, "Non-cavitary hemorrhage producing shock in trauma patients: incidence and severity," Journal of Trauma, vol. 29, no. 2, pp. 219-222, 1989.

[2] K. E. Hall, M. K. Holowaychuk, C. R. Sharp, and E. Reineke, "Multicenter prospective evaluation of dogs with trauma," Journal of the American Veterinary Medical Association, vol. 244, no. 3, pp. 300-308, 2014.

[3] D. Rixen and J. H. Siegel, "Bench-to-bedside review: oxygen debt and its metabolic correlates as quantifiers of the severity of hemorrhagic and posttraumatic shock," Critical Care, vol. 9, no. 5, pp. 441-453, 2005.

[4] A. Fülöp, Z. Turóczi, D. Garbaisz, L. Harsányi, and A. Szijártó, "Experimental models of hemorrhagic shock: a review," European Surgical Research, vol. 50, no. 2, pp. 57-70, 2013.

[5] J. H. Siegel, M. Fabian, J. A. Smith, E. P. Kingston, K. A. Steele, and M. R. Wells, "Oxygen debt criteria quantify the effectiveness of early partial resuscitation after hypovolemic hemorrhagic shock," Journal of Trauma: Injury Infection \& Critical Care, vol. 54, no. 5, pp. 862-880, 2003.

[6] R. W. Barbee, P. S. Reynolds, and K. R. Ward, "Assessing shock resuscitation strategies by oxygen debt repayment," Shock, vol. 33, no. 2, pp. 113-122, 2010.

[7] J. Creteur and J. L. Vincent, "Potential uses of hemoglobinbased oxygen carriers in critical care medicine," Critical Care Clinics, vol. 25, no. 2, pp. 311-324, 2009.

[8] R. B. Weiskoph, "Hemoglobin-based oxygen carriers: disclosed history and the way ahead: the relativity of safety," Anesthesia of Analgesia, vol. 119, no. 4, pp. 758-760, 2014.

[9] P. Cabrales and M. Intaglietta, "Blood substitutes: evolution from noncarrying to oxygen- and gas-carrying fluids," ASAIO Journal, vol. 59, no. 4, pp. 337-354, 2013.

[10] P. W. Buehler, F. D’Agnillo, and D. J. Schaer, "Hemoglobin-based oxygen carriers: from mechanisms of toxicity and clearance to rational drug design," Trends in Molecular Medicine, vol. 16, no. 10, pp. 447-457, 2010.

[11] R. M. Winslow, "Oxygen: the poison is in the dose," Transfusion, vol. 53, no. 2, pp. 424-437, 2013.

[12] V. Fonseca, J. Avizinis, P. Moon-Massat, D. Freilich, H. W. Kim, and C.-M. Hai, "Differential sensitivities of pulmonary and coronary arteries to hemoglobin-based oxygen carriers and nitrovasodilators: study in a bovine ex vivo model of vascular strips," Vascular Pharmacology, vol. 52, no. 5-6, pp. 215-223, 2010.

[13] P. Cabrales, "Low oxygen-affinity hemoglobin solution increases oxygenation of partially ischemic tissue during acute anemia," Journal of the American College of Surgeons, vol. 210, no. 3, pp. 271-279, 2010. 
[14] D. Ortiz, M. Barros, S. Yan, and P. Cabrales, "Resuscitation from hemorrhagic shock using polymerized hemoglobin compared to blood," The American Journal of Emergency Medicine, vol. 32, no. 3, pp. 248-255, 2014.

[15] M. M. Hoeper, H. J. Bogaard, R. Condliffe et al., "Definitions and diagnosis of pulmonary hypertension," Journal of the American College of Cardiology, vol. 62, no. 25, pp. D42-D50, 2013.

[16] D. Freilich, L. B. Pearce, A. Pitman et al., "HBOC-201 vasoactivity in a phase III clinical trial in orthopedic surgery subjectsextrapolation of potential risk for acute trauma trials," Journal of Trauma, vol. 66, no. 2, pp. 365-376, 2009.

[17] T. Standl, P. Horn, S. Wilhelm et al., "Bovine haemoglobin is more potent than autologous red blood cells in restoring muscular tissue oxygenation after profound isovolaemic haemodilution in dogs," Canadian Journal of Anaesthesia, vol. 43, no. 7, pp. 714-723, 1996.

[18] C. M. Fitzpatrick, K. L. Biggs, B. Z. Atkins et al., "Prolonged lowvolume resuscitation with HBOC-201 in a large-animal survival model of controlled hemorrhage," Journal of Trauma-Injury, Infection and Critical Care, vol. 59, no. 2, pp. 273-283, 2005.

[19] J. Rice, N. Philbin, G. McGwin et al., "Bovine polymerized hemoglobin versus hextend resuscitation in a swine model of severe controlled hemorrhagic shock with delay to definitive care," Shock, vol. 26, no. 3, pp. 302-310, 2006.

[20] I. George, G.-H. Yi, A. R. Schulman et al., "A polymerized bovine hemoglobin oxygen carrier preserves regional myocardial function and reduces infarct size after acute myocardial ischemia," American Journal of Physiology: Heart and Circulatory Physiology, vol. 291, no. 3, pp. H1126-H1137, 2006.

[21] D. Ortiz, M. Barros, S. Yan, and P. Cabrales, "Resuscitation from hemorrhagic shock using polymerized hemoglobin compared to blood," American Journal of Emergency Medicine, vol. 32, no. 3, pp. 248-255, 2014.

[22] P. W. Buehler and A. I. Alayash, "All hemoglobin-based oxygen carriers are not created equally," Biochimica et Biophysica Acta: Proteins and Proteomics, vol. 1784, no. 10, pp. 1378-1381, 2008.

[23] P. Cabrales and J. M. Friedman, "HBOC vasoactivity: interplay between nitric oxide scavenging and capacity to generate bioactive nitric oxide species," Antioxidants and Redox Signaling, vol. 18, no. 17, pp. 2284-2297, 2013.

[24] P. Cabrales, A. G. Tsai, and M. Intaglietta, "Balance between vasoconstriction and enhanced oxygen delivery," Transfusion, vol. 48, no. 10, pp. 2087-2095, 2008.

[25] B. Driessen, J. S. Jahr, F. Lurie, S. M. Griffey, and R. A. Gunther, "Effects of haemoglobin-based oxygen carrier Hemoglobin glutamer-200 (bovine) on intestinal perfusion and oxygenation in a canine hypovolaemia model," The British Journal of Anaesthesia, vol. 86, no. 5, pp. 683-692, 2001.

[26] H. Kerger, D. J. Saltzman, M. D. Menger, K. Messmer, and M. Intaglietta, "Systemic and subcutaneous microvascular Po2 dissociation during 4-h hemorrhagic shock in conscious hamsters," American Journal of Physiology: Heart and Circulatory Physiology, vol. 270, no. 3, part 2, pp. H827-H836, 1996.

[27] P. Cabrales, A. G. Tsai, and M. Intaglietta, "Polymerized bovine hemoglobin can improve small-volume resuscitation from hemorrhagic shock in hamsters," Shock, vol. 31, no. 3, pp. 300$307,2009$.

[28] M. T. Gladwin, T. Kanias, and D. B. Kim-Shapiro, "Hemolysis and cell-free hemoglobin drive an intrinsic mechanism for human disease," Journal of Clinical Investigation, vol. 122, no. 4, pp. 1205-1208, 2012.

[29] R. Lever, M. J. Rose, E. A. McKenzie, and C. P. Page, "Heparanase induces inflammatory cell recruitment in vivo by promoting adhesion to vascular endothelium," The American Journal of Physiology-Cell Physiology, vol. 306, no. 12, pp. C1184-C1190, 2014.

[30] T. Iba and T. Takayama, "Enoxaparin attenuates endothelial damage with less bleeding compared with unfractionated heparin in endotoxemic rats," Shock, vol. 32, no. 5, pp. 530-534, 2009.

[31] S. O. P. Hofer, A. J. van der Kleij, P. F. Grundeman, E. W. Scholten, and P. J. Klopper, "Critical tissue oxygen tension defines tissue oxygen debt in the isolated hindlimb of the pig during progressive ischemia," Critical Care Medicine, vol. 23, no. 5, pp. 931-938, 1995.

[32] W. G. Sheridan, R. H. Lowndes, G. T. Williams, and H. L. Young, "Determination of a critical level of tissue oxygenation in acute intestinal ischaemia," Gut, vol. 33, no. 6, pp. 762-766, 1992.

[33] F. Arnaud, A. H. Scultetus, A. Haque et al., "Sodium nitroprusside ameliorates systemic but not pulmonary HBOC-201induced vasoconstriction: an exploratory study in a swine controlled haemorrhage model," Resuscitation, vol. 83, no. 8, pp. 1038-1045, 2012.

[34] D. M. Baron, A. Beloiartsev, A. Nakagawa et al., "Adverse effects of hemorrhagic shock resuscitation with stored blood are ameliorated by inhaled nitric oxide in lambs," Critical Care Medicine, vol. 41, no. 11, pp. 2492-2501, 2013.

[35] V. Fonseca, J. Avizinis, P. Moon-Massat, D. Freilich, H. W. Kim, and C.-M. Hai, "Differential sensitivities of pulmonary and coronary arteries to hemoglobin-based oxygen carriers and nitrovasodilators: Study in a bovine ex vivo model of vascular strips," Vascular Pharmacology, vol. 52, no. 5-6, pp. 215-223, 2010.

[36] J. R. Hess, V. W. MacDonald, and W. W. Brinkley, "Systemic and pulmonary hypertension after resuscitation with cell-free hemoglobin," Journal of Applied Physiology, vol. 74, no. 4, pp. 1769-1778, 1993. 


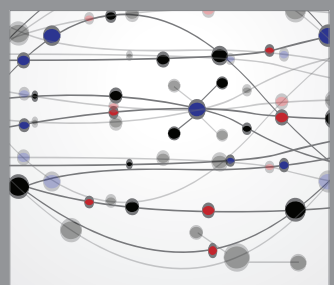

The Scientific World Journal
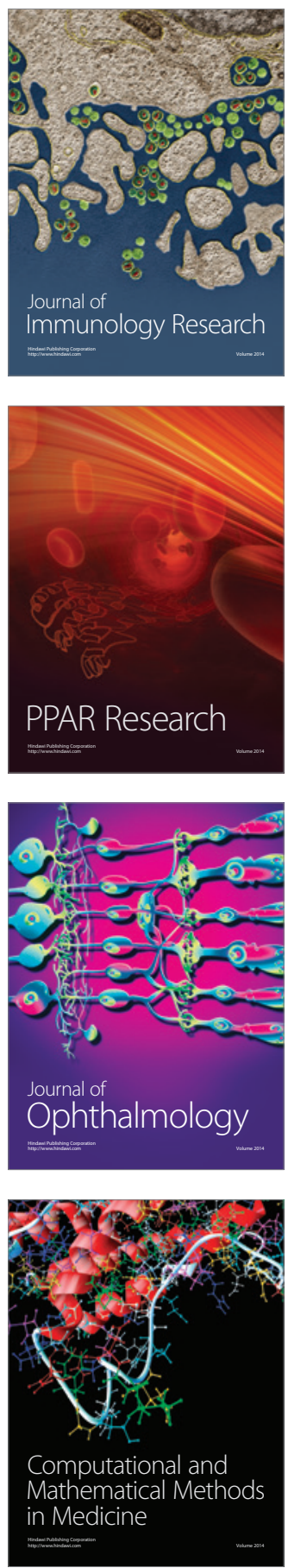

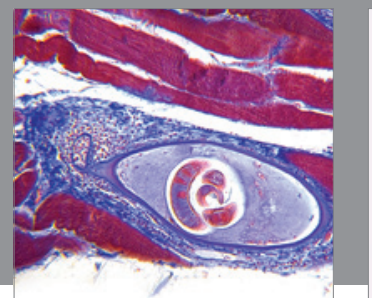

Gastroenterology

Research and Practice
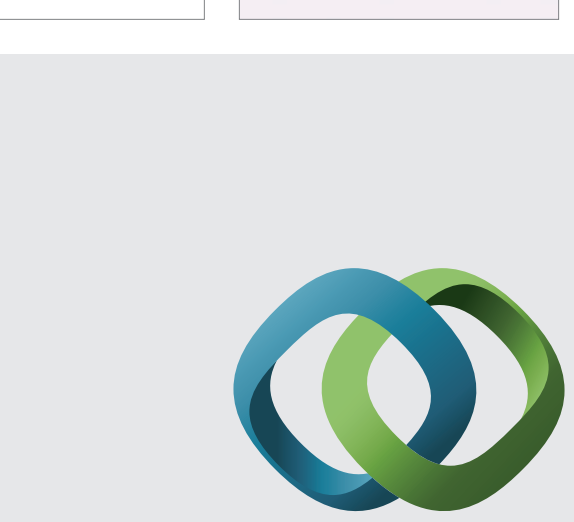

\section{Hindawi}

Submit your manuscripts at

http://www.hindawi.com
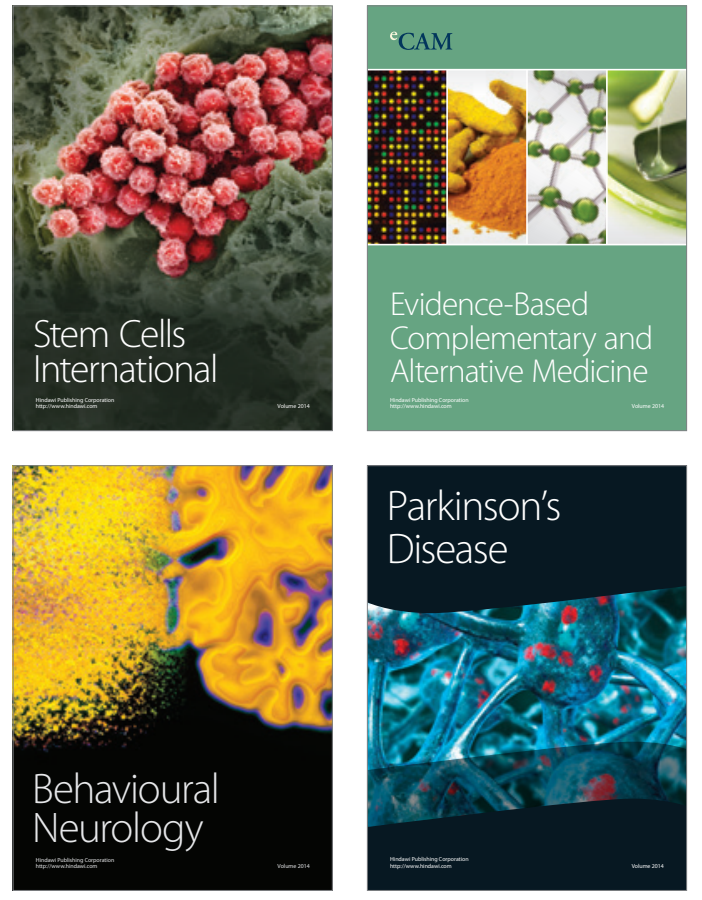
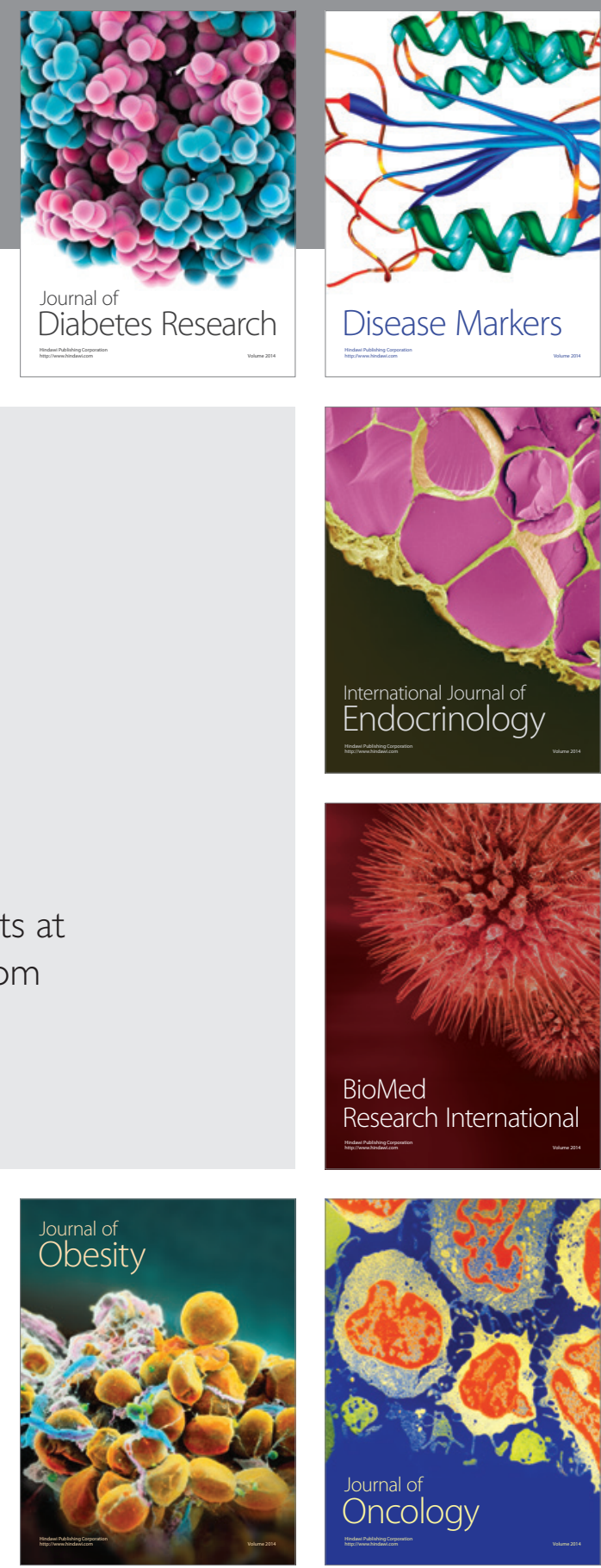

Disease Markers
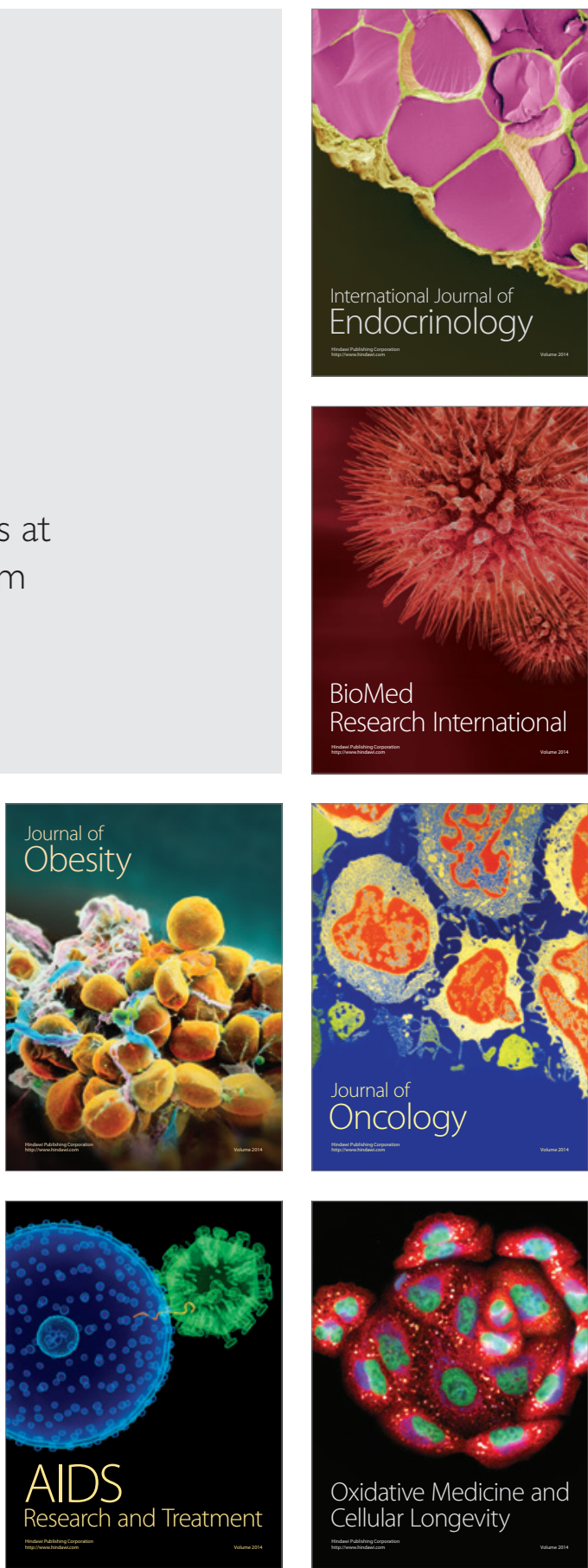